
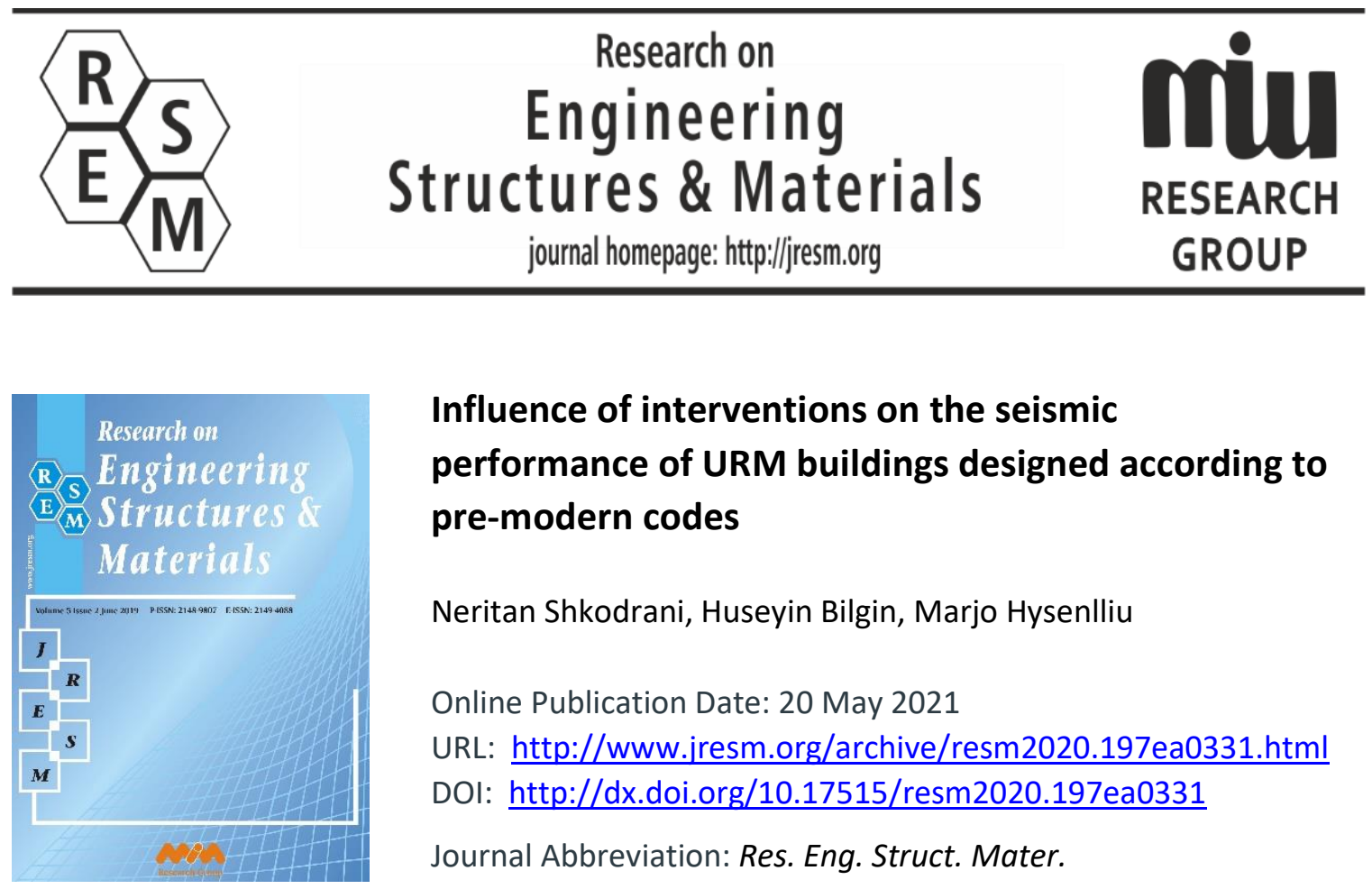

\title{
Influence of interventions on the seismic performance of URM buildings designed according to pre-modern codes
}

Neritan Shkodrani, Huseyin Bilgin, Marjo Hysenlliu

Online Publication Date: 20 May 2021

URL: http://www.jresm.org/archive/resm2020.197ea0331.html

DOI: http://dx.doi.org/10.17515/resm2020.197ea0331

Journal Abbreviation: Res. Eng. Struct. Mater.

\section{To cite this article}

Shkodrani N, Bilgin $\mathrm{H}$, Hysenlliu M. Influence of interventions on the seismic performance of URM buildings designed according to pre-modern codes. Res. Eng. Struct. Mater., 2021; 7(2): 315-330.

\section{Disclaimer}

All the opinions and statements expressed in the papers are on the responsibility of author(s) and are not to be regarded as those of the journal of Research on Engineering Structures and Materials (RESM) organization or related parties. The publishers make no warranty, explicit or implied, or make any representation with respect to the contents of any article will be complete or accurate or up to date. The accuracy of any instructions, equations, or other information should be independently verified. The publisher and related parties shall not be liable for any loss, actions, claims, proceedings, demand or costs or damages whatsoever or howsoever caused arising directly or indirectly in connection with use of the information given in the journal or related means.

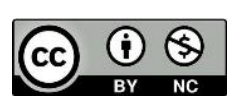

Published articles are freely available to users under the terms of Creative Commons Attribution - NonCommercial 4.0 International Public License, as currently displayed at here (the "CC BY - NC"). 


\title{
Research on Engineering Structures \& Materials
}

journal homepage: http://jresm.org

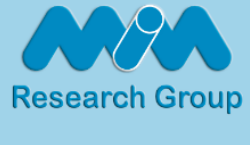

Research Article

\section{Influence of interventions on the seismic performance of URM buildings designed according to pre-modern codes}

\author{
Neritan Shkodrani 1, a, Huseyin Bilgin ${ }^{* 2, b}$, Marjo Hysenlliu 1, c \\ ${ }^{1}$ Department of Civil Engineering, Polytechnic University of Tirana, Albania \\ ${ }^{2}$ Department of Civil Engineering, EPOKA University, Tirana, Albania
}

\begin{tabular}{|c|c|}
\hline Article Info & Abstract \\
\hline & On November 26,2019, an earthquake of magnitude 6.4 hit Durres city, Albania. \\
\hline Article history: & After the earthquake, the inspection carried out by the authors in the region has \\
\hline Received: 31 May 2020 & provided relevant findings regarding the methods of construction, quality of the \\
\hline Revised: 20 Apr 2021 & materials and the performance of structures. The dominant building types in the \\
\hline Accepted: 16 May 2021 & Albanian building stock comprise unreinforced masonry (URM) structures with \\
\hline Keywords: & $\begin{array}{l}\text { load-bearing masonry walls. These units suffered the worst damage. Dynamic } \\
\text { response of masonry is highly nonlinear, and generally shows high vulnerability } \\
\text { to seismic loading. Moreover, many buildings of these type have undergone }\end{array}$ \\
\hline URM buildings; & structural interventions like adding floors, or wall openings, especially in the \\
\hline Pushover analysis; & first floors of the buildings, which are parallel to the main roads, because of great \\
\hline 2019 Albania & demand for shops and stores. This paper aims at making seismic performance \\
\hline Earthquake; & assessment of the intervened buildings based on macro-element modeling \\
\hline Template projects. & approach. Due to its efficiency, this approach is becoming popular among the \\
\hline & practitioners and field experts in this area and allows simulating the non-linear \\
\hline & behavior of masonry buildings. This method is applied to two old masonry \\
\hline & $\begin{array}{l}\text { buildings from the Albanian construction practice that are representatives of } \\
\text { mid-size residential buildings with and without interventions. It must be said }\end{array}$ \\
\hline & that in Albania, masonry buildings have been built using templates all over the \\
\hline & $\begin{array}{l}\text { country, so both models with and without intervention are common. Capacity } \\
\text { curves of the investigated buildings are derived to assess the most probable }\end{array}$ \\
\hline & $\begin{array}{l}\text { seismic response of the investigated housing construction in the region as well } \\
\text { as to evaluate the seismic performance of the tested structures. }\end{array}$ \\
\hline
\end{tabular}

(C) 2021 MIM Research Group. All rights reserved.

\section{Introduction}

The recent seismic activities that affected many areas of Albania in 2019 clearly showed how much attention should be taken of existing masonry building stock and its preservation. Evaluating the earthquake damage potential of a masonry building may be a challenging task to achieve, considering how peculiar these structures are, necessitating advanced and computationally rigorous numerical models to have an accurate estimation of their dynamical behavior to seismic actions. Recent Albanian earthquakes (Durres 2019 Seismic sequences) caused irreparable damages to many masonry structures all over the country [1-2].

Understanding the historical earthquake activity of any place is essential to recognize the possibility that an earthquake can affect the territory again and to consider the extent of possible damage. While the second is a function of the vulnerability, the first warns us of the main hazard.

\footnotetext{
${ }^{*}$ Corresponding author: hbilgin@epoka.edu.al

a orcid.org/0000-0002-8638-9664; b orcid.org/0000-0002-5261-3939; c orcid.org/0000-0002-0863-2112

DOI: http://dx.doi.org/10.17515/resm2020.197ea0331

Res. Eng. Struct. Mat. Vol. 7 Iss. 2 (2021) 315-330 
Throughout the history, earthquakes in Albania, like in many earthquake-prone countries in the region, have seriously affected built environment causing numerous human casualties and economic loses [3-9]. In this regard, buildings' vulnerability is a key concept to focus on to mitigate the consequences of seismic events. Generally, URM buildings present a poorer seismic performance as compared to reinforced concrete buildings due to the low ductility, strength, and rigidity of their inherent components. Consequently, modern seismic guidelines include recommendations and commentaries aimed at reducing their seismic vulnerability. However, a significant part of existing masonry building stock has been built per pre-modern codes, thus considering unrestrictive conditions [10-11].

The dominant building types in the Albanian territory consist of URM structures with loadbearing masonry walls and buildings with RC framing system and infill baked clay and/or concrete walls. Most of them have been designed according to the KTPs-Albanian Technical Codes, which were first issued and implemented as a legal provision in 1963 and last amended in 1989 and still in force. Majority of the existing masonry buildings in the country, like in many other European countries were designed considering earlier seismic codes [12-14]. Nevertheless, its compliance requirements were not as explicit as those established by recent modern seismic codes like Eurocode 6 [15] and Eurocode 8 [16] from European practice. This led to a lack of seismic considerations in building's design process.

The URM structures with the load-bearing masonry walls suffered the most by the November 26, 2019 Durrës Earthquake sequences due to reasons including poor quality of construction, aging, climatological effects, poor workmanship, interventions made by people, the design code of the time, lack of preservation and insufficient repair after former damaging seismic events. URM buildings suffered not only non-structural but also structural damage including partial or total collapse of the load-bearing masonry walls.

The seismic response of masonry buildings is affected by the presence of openings on the load bearing walls. Even though most of the existing masonry buildings satisfy the regularity criteria according to seismic regulations, they may have structural systems composed of irregular walls with openings. Such irregularities can arise from the lack of conceptual seismic design or even due to the creation / closure of openings influenced by architectural or structural reasons. These geometric irregularities can significantly affect the earthquake response of masonry walls by causing not only a nonuniform distribution of gravity loads on masonry panels but also a concentration of displacement demands in some parts of the walls. In Albania, many URM buildings have undergone structural interventions like adding floors, or wall openings, especially in the first floors of the buildings, which are parallel to the main roads, because of great demand for shops and stores. The seismic response of such masonry buildings can only be effectively modeled with a good knowledge of the inelastic response of individual walls with openings.

This study aims at investigating the influence of wall openings on the first floor of the selected URM buildings. In order to make a comparative assessment, two URM buildings with and without interventions, having the same initial architectural and structural design were selected and modelled by using the TREMURI [17]. Structural features such as member dimensions, material types and loading conditions of the buildings were determined from their architectural and structural designs projects and field investigations on investigated buildings. Mechanical features were determined experimentally and adopted for mathematical modeling. Pushover analyses have been deployed to obtain the seismic capacities, the performance points and the damage level states according to Eurocode 8 by using 3Muri software package [17]. 


\section{Seismicity of Albanian Territory}

Balkan neighborhood is in a complicated seismotectonic region and prone to earthquakes. A high frequency of earthquakes has been experienced, resulting in loss of life and property destruction in the region [18-19]. Faulting zones in Eastern part of the Albania are typically defined by the influence of normal faults [20]. The western fault regions are characterized by reverse faulting- at the range of $40-50 \%$ extending along the coastal shore, while the appearance of strike-slip faults is in range of $15 \%$ of whole tectonic activity. The influence of normal faulting style ranges from $30-40 \%$ in this case very close to the major directivity of trust-fault type.

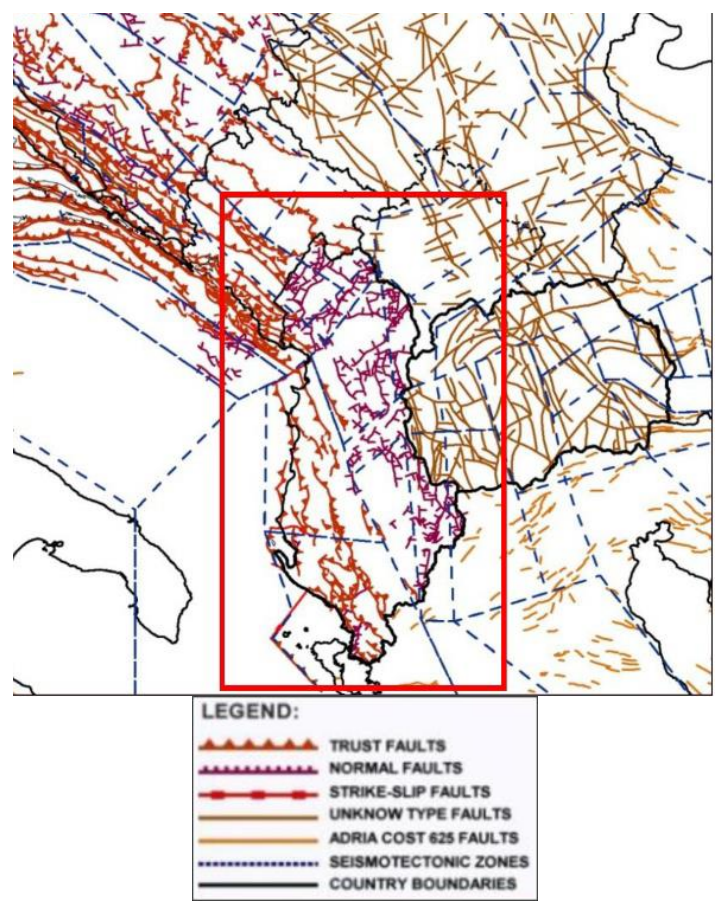

Fig. 1 Types of faults affecting the region [20]

Two transverse and three longitudinal active fault zones are evidenced into the Albanian orogen (Fig. 1). It has been concluded that the major seismic activity is located along the following seismic belts [21]:

- The NW up to nearly NNW trending Ionian-Adriatic thrust fault zone,

- The NW trending Shkodra-Mati-Librazhd graben fault zone,

- The N-S trending Peshkopi-Korça graben fault zone,

- The NE trending Shkodra-Tropoja normal fault zone,

- The NE trending Elbasan-Dibra normal fault zone. 


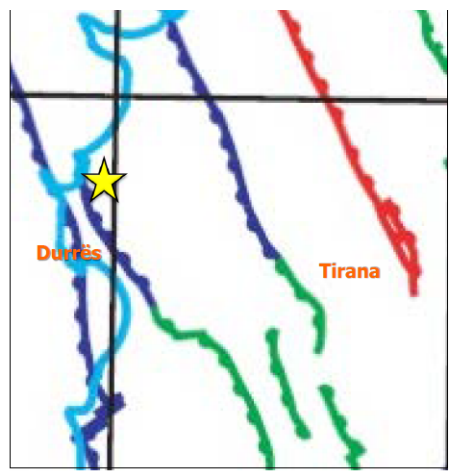

Fig. 2 Active fault zones and faults of the November 26, 2019 affected area

The 2019 earthquake affected area is dominated by NW-SE striking reverse active faults. Blue lines correspond to faults triggered during Middle Pleistocene-Holocene, the green lines to faults triggered during Pliocene-Lower Pleistocene and the red lines to faults activated during Pre-Pliocene period (Fig. 2). The star corresponds to the epicenter of the Mw 6.4 Durrës earthquake occurred on November 26, 2019.

\subsection{November 26, 2019 Earthquake and Seismic Hazard Maps of Albania}

An earthquake hit the central western part of Albanian territory on November 26, 2019. It was evaluated as Mw 6.4 (Fig. 3). Its focal depth was about $10 \mathrm{~km}$ [USGS, 2019]. According to the several seismological institutes and observations, the main shock was caused by the activation of a NW-SE striking reverse fault. The main shock was felt in the neighboring countries.

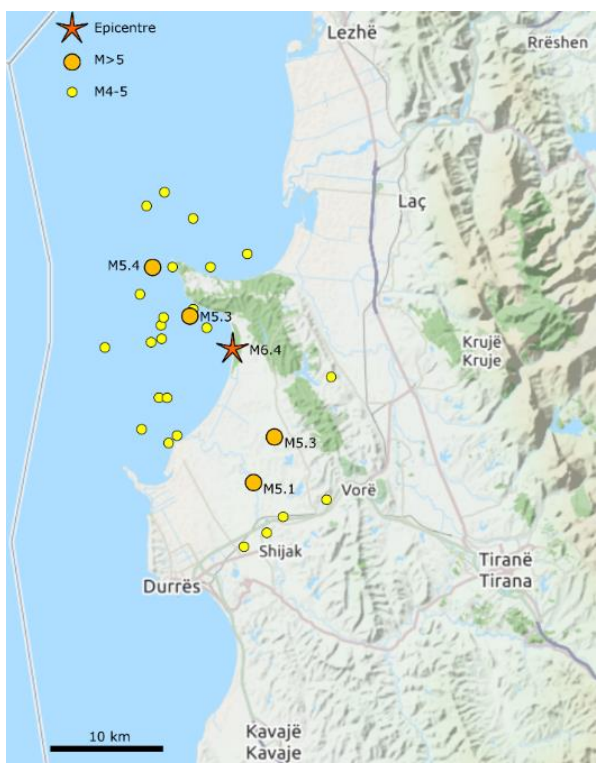

Fig. 3 The epicenter and location of aftershocks in the first month of the 26 November 2019 earthquake

The main shock and the aftershocks caused damage to buildings of Durrës, Tirana and several settlements of the wider area. Building damage was distributed along an elliptical 
region (Fig. 4). This area coincides with the strike of the seismogenic fault as it is derived from the fault plane solutions provided by several seismological institutes and observatories [INGV, 2019 and USGS, 2019]. This area could be characterized as macroseismic epicenters as the result of the interaction between the seismotectonic setting and the local soil conditions and as the result of several reflections, refractions, directivity phenomena of seismic waves and resonance resulting in destruction in the earthquake-affected regions.

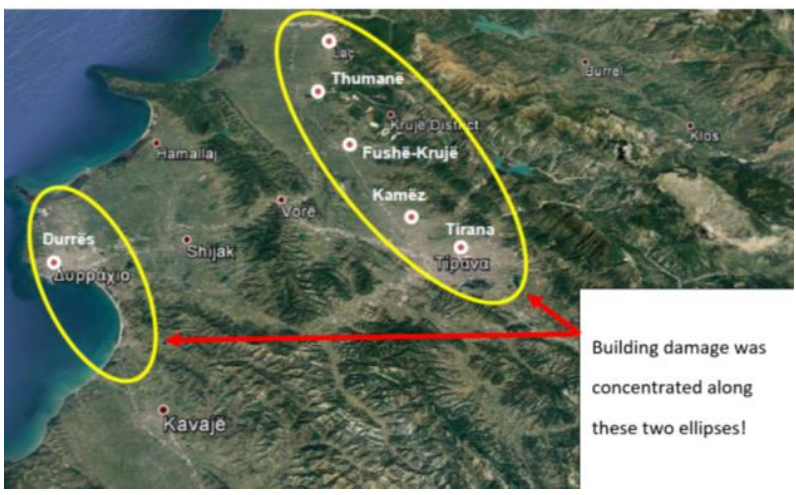

Fig. 4 Earthquake-affected region of 2019 Durres (Albania) earthquake

Based on the seismic map of Albania, published by Ministry of Construction (1989), it can be observed that the resulted intensities from this earthquake, are within the boundaries suggested in the Seismic Zonation Map (Fig. 5)

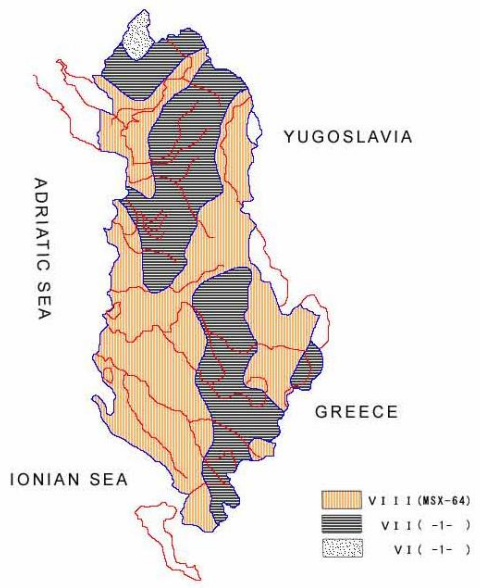

Fig. 5 Seismic intensity zonation map of Albania [22]

\section{Description of the Case Study Buildings}

Masonry building stock in Albania are mostly composed of template designs of low to midrise buildings. The structure is principally comprised of stiff walls with several openings and the diaphragms constructed by RC slabs. For the scope of this study, a typified URM mid-rise building is selected as a representative in the region. The masonry building, which has been analyzed, has five stories in its original design. However, by time due to the 
demand in line with the increment in population and needs for several purposes, this template has been modified by opening some new spaces on the ground floor keeping the architectural features same above this floor.

The main dimensions of the load bearing system of the building blocks were determined with in-situ site investigations. Analyses was carried out according to the prepared load bearing system dimensions. Since the buildings under investigation are old ones, limited number of architectural drawings or details of the initial conditions of the building were reached. Therefore, a detailed inspection of the existing structures was extracted. In these plans, the location and dimensions of the walls, windows and doors were determined. Based on the measurements obtained, structural floor plans of the existing structures were prepared, and structural models were developed accordingly for seismic analysis.

This template is of year 1972, referred as 72/1 in the manual of Albanian Construction Institute. This building has plan dimensions of $(18.32 \times 12.43) \mathrm{m}$. It has 5 story high with $285 \mathrm{~cm}$ height for each story. The load bearing walls are built with clay bricks M75 (strength $7.5 \mathrm{MPa}$ ). The mortar is $\mathrm{M} 25$ of strength $2.5 \mathrm{MPa}$. The wall thickness is $38 \mathrm{~cm}$ in the first and second floor, then $25 \mathrm{~cm}$ on the remaining. The partition walls are with hollow clay bricks. The concrete corner columns and slabs are constructed with M150 concrete. There are two buildings of this template, 5 floors each but in one intervention is done on the first floor (Fig. 6-7). In one side of the first story, walls are replaced with reinforced concrete frames, with 5 openings as shown (Fig. 7). Columns are of reinforced concrete C20/25 with dimensions of $(40 \times 40) \mathrm{cm} 2$ and steel reinforcement $B 400$ with $A_{s}=A_{s}^{\prime}=$ $12.56 \mathrm{~cm}^{2}$ and stirrups $\varphi 8$ every $15 \mathrm{~cm}$. Beams are also of reinforced concrete $\mathrm{C} 20 / 25$ with dimensions of $(30 \times 50) \mathrm{cm} 2$ and steel reinforcement $B 400$ with $A_{s}=A_{s}^{\prime}=3.14 \mathrm{~cm}^{2}$ and stirrups $\varphi 8$ every $20 \mathrm{~cm}$.

In order to characterize the strength and structural integrity of the structure, mechanical characteristics of the masonry material are assessed from the experimental tests. It consists of strength tests on brick units and mortar samples, as well as tests on small masonry assemblages, such as compression and shear tests on triplets. The clay bricks were tested in compression according to EN 772-1 (2000) [23]. The flexural and compressive strength of the mortar were defined according to the prescriptions of EN 1015-11 [24]. These tests allowed the determination of the compressive strength of masonry $\left(f_{m}\right)$. Specimens of masonry were also subjected to the shear test for the determination of the initial shear strength $\left(f_{v 0}\right)$ and the friction coefficient $(\mu)$, according to the guidelines given by EN 1052-3 [25]. According to the test results, clay bricks and the mortar inherent characteristics are given as follows:

Brick tests: $\mathrm{f}_{\mathrm{b}}=7.3 \mathrm{MPa} \mathrm{f}_{\mathrm{bt}}=1.9 \mathrm{MPa} \rho_{\mathrm{b}}=1705 \mathrm{~kg} / \mathrm{m}^{3}$

Mortar tests: $\mathrm{f}_{\mathrm{m}}=2.4 \mathrm{MPa} \mathrm{f}_{\mathrm{mt}}=0.62 \mathrm{MPa}$

Masonry tests: $\mathrm{f}_{\mathrm{k}}=1.97 \mathrm{MPa} \mathrm{f}_{\mathrm{vk}}=0.35 \mathrm{f}_{\mathrm{vk} 0}=0.18$ 


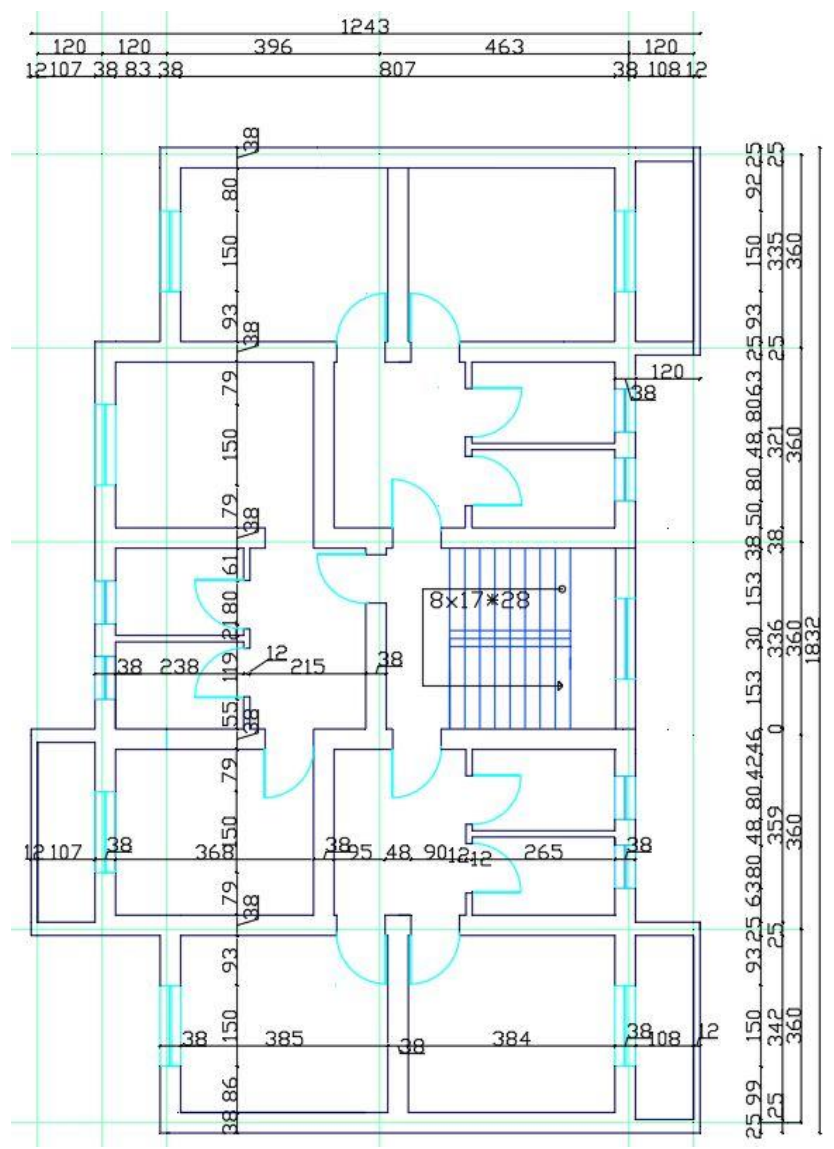

Fig. 6 Typical plan view of the selected masonry building before intervention 


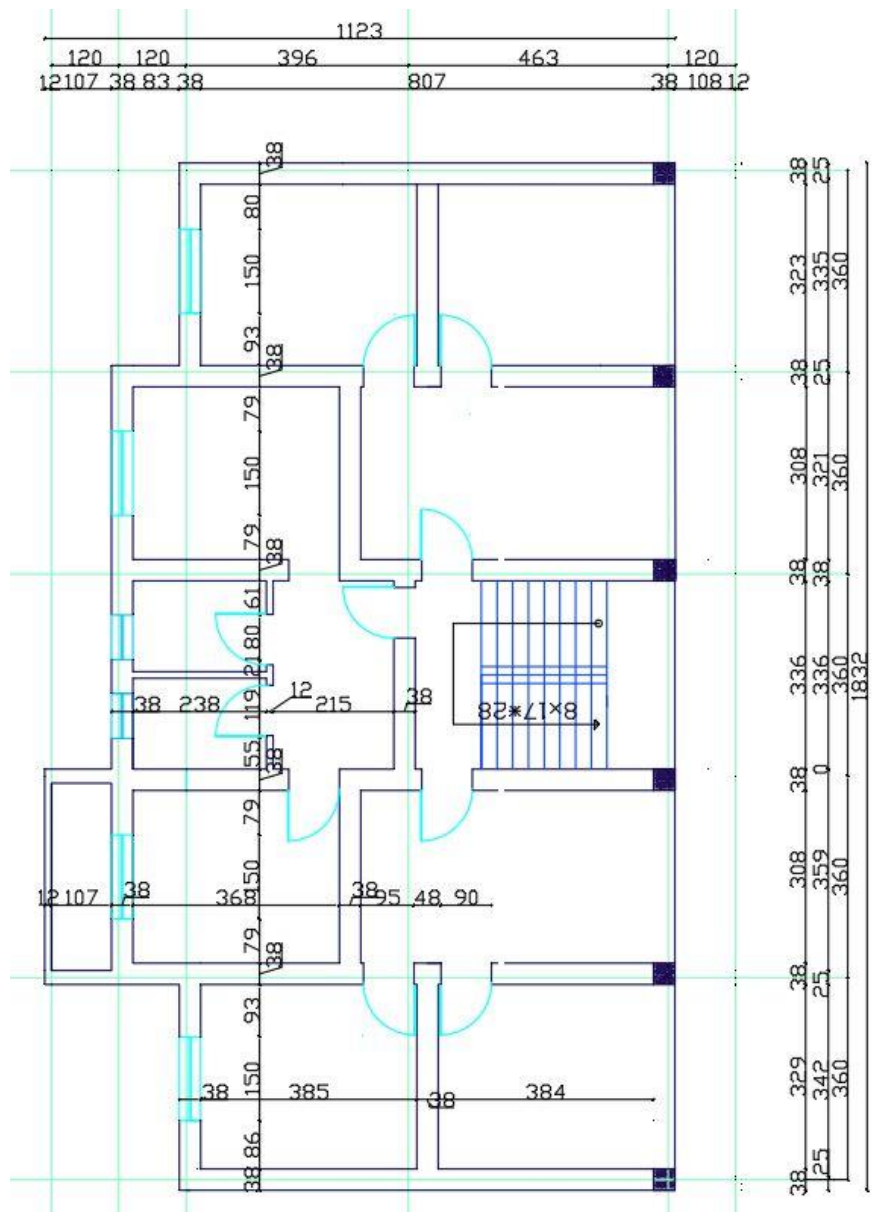

Fig. 7 Typical plan view of the selected masonry building after intervention in the $1^{\text {st }}$ story

\section{Mathematical Modeling}

Masonry bricks units and the mortar are the two main units of the masonry structures. Mechanical properties of this heterogeneous materials depend on the inherent characteristics of its constituents. Its behavior can be quite complex under simple static loadings. To simulate the response of URM structures, numerous theories are developed, and numerical models are proposed in the literature [26]. The adopted model in this paper is macro-modelling approach. In this approach, each wall is characterized by discretized components that have the same properties. TREMURI [17] is used to perform the numerical analysis. The nonlinear macro-element method, suggested by Gambarotta and Lagomarsino [27], allows with a partial number of degrees of freedom, to characterize the two main in-plane failure modes, shear-sliding and bending-rocking mechanisms.

The conventional macro-element used for nonlinear static analyses is sketched with the kinematic model depicted in Fig. 8a. The 3D model of the examined masonry buildings, where it is apparent that masonry walls are modelled through a mesh of masonry piers and spandrels, is depicted in Fig. 8b. 

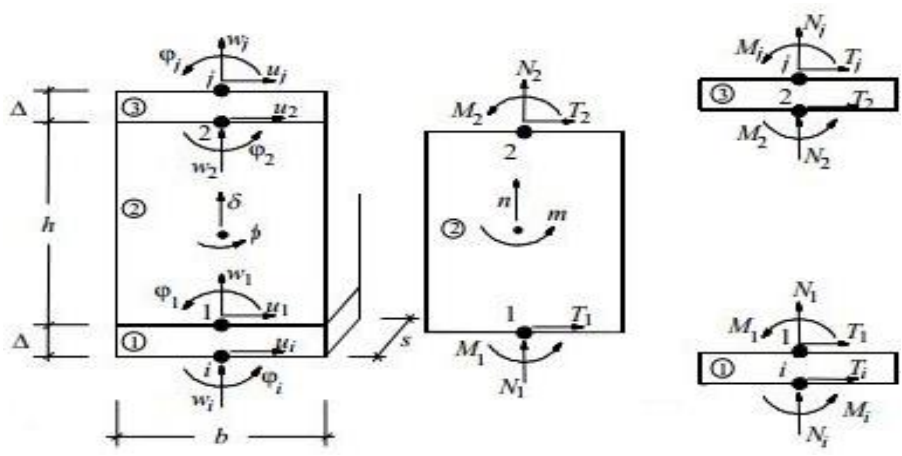

(a)
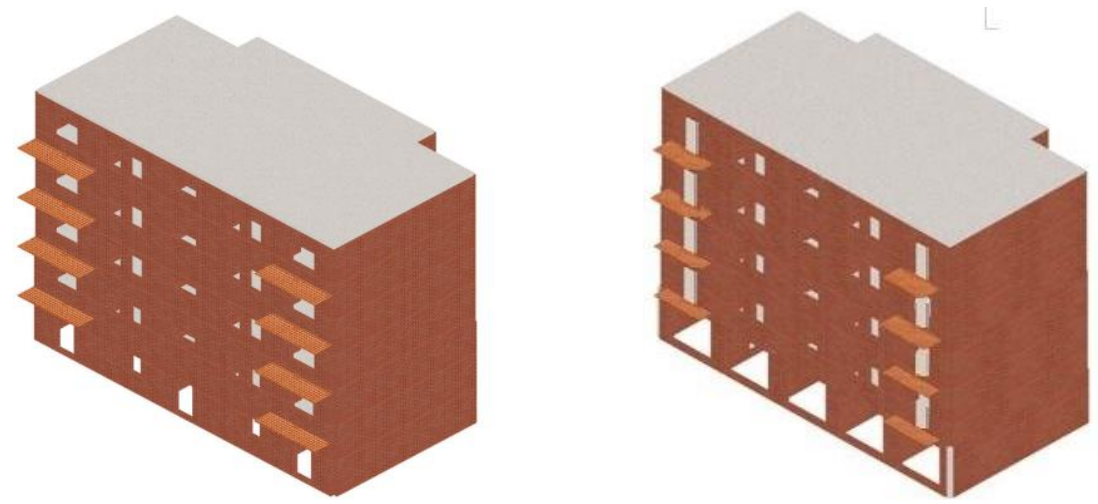

(b)

Fig. 8 a) The macro-element kinematic model; b) the 3D building model with (right) and without (left) interventions setup through the TREMURI software.

Seismic capacity of both buildings is obtained by nonlinear static analyses.

\section{Results}

\subsection{Dynamic Characteristics}

The modal analysis was performed for both building models and the results were presented for first three modes of vibrations. The results of the linear modal dynamic analyses were synthesized in Table 1. 
Table 1. Modal Analyses results for the first 3 modes of vibration

\begin{tabular}{cccccc}
\hline Building Type & Mode & Period $(\mathrm{sec})$ & $\mathrm{M}_{\mathrm{x}}(\%)$ & $\mathrm{M}_{\mathrm{y}}(\%)$ & $\mathrm{M}_{\mathrm{z}}(\%)$ \\
\hline \multirow{3}{*}{ Original Building } & 1 & 0.244 & 0.01 & 72.74 & 0.03 \\
& 2 & 0.230 & 75.60 & 0.01 & 0.00 \\
& 3 & 0.190 & 0.41 & 0.05 & 0.00 \\
Building with & 1 & 0.235 & 76.92 & 1.62 & 0.00 \\
intervention & 2 & 0.223 & 1.83 & 70.57 & 0.07 \\
& 3 & 0.190 & 0.71 & 0.06 & 0.00 \\
\hline
\end{tabular}

\subsection{Seismic Capacity Assessment}

There are several useful structural analysis parameters to determine earthquake risk [2829]. Pushover analyses are useful tools for the assessment of URM wall capacities. The seismic response has been analyzed by using pushover analysis; under the constant gravity load and a monotonically increasing horizontal loads. Based on this methodology, the influence of the earthquake loads has been assessed by applying two systems of lateral forces orthogonal to each other. The behavior of the building is characterized by capacity curve which usually describes the relation between the base-shear force and roof displacement. It could be also plotted in acceleration displacement response spectrum format together with the response spectrum curve and estimate the top story displacement under the design earthquake to obtain the performance point of the building.

In the TREMURI, two load patterns are deployed: proportional with the 1st mode shape, based on the fundamental mode shape of the building, and a uniform load distribution to all stories. The two are performed in two orthogonal directions $\mathrm{x}$ - and $\mathrm{y}$ - and with positive and negative values. So, in total eight analysis: $+x$ MF1, $+x$ uniform, $-x$ MF1, $-x$ uniform, $+y$ MF1, +y uniform, -y MF1, -y uniform (Fig. 9). These analyses are repeated for each combination. Without eccentricity of gravity load and with eccentricity of two different levels. For both simulations representing the original and intervened building are computed 24 analyses, for all load combinations, earthquake direction, with and without eccentricity. The numbers shown in the legend of capacity curves (Fig. 10-11) represents the eccentricity of the load application point.

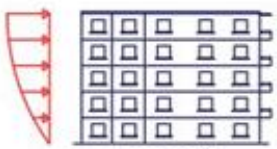
ry stevie roset
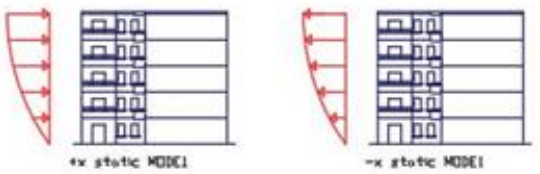

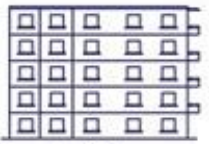

sy unitorn

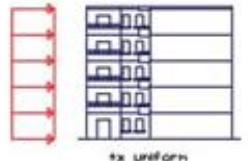

$\rightarrow x$ wetion

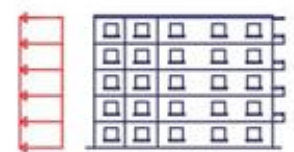

-y nifforn
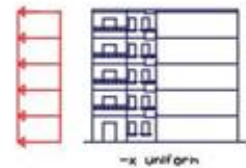

Fig. 9 Load patterns used of pushover analyses

Upon finishing the modeling, the capacity curves of both buildings were estimated by carrying out nonlinear static analysis in TREMURI (Fig. 10-11). Gravity load of the buildings were evaluated by considering the combination of Dead and Live loads. 


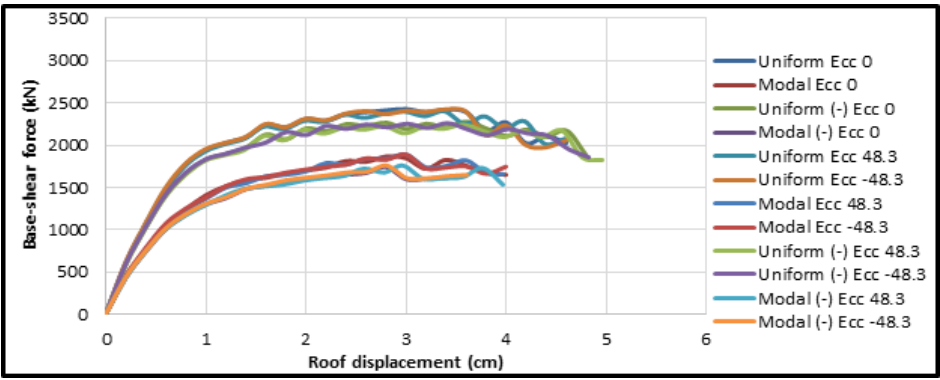

a) $x$ - direction

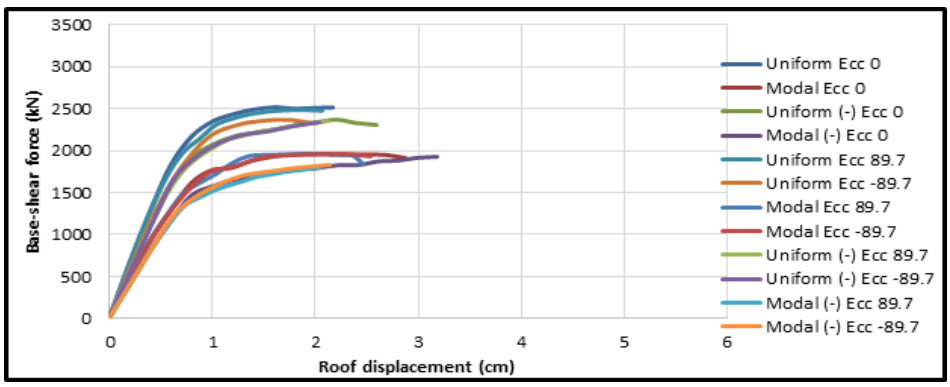

b) $y$-direction

Fig. 10 Capacity curves of the URM building without intervention

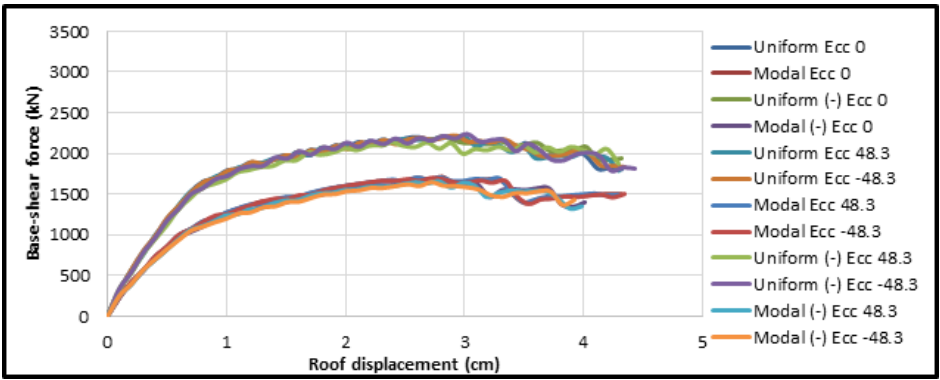

a) $x$ - direction

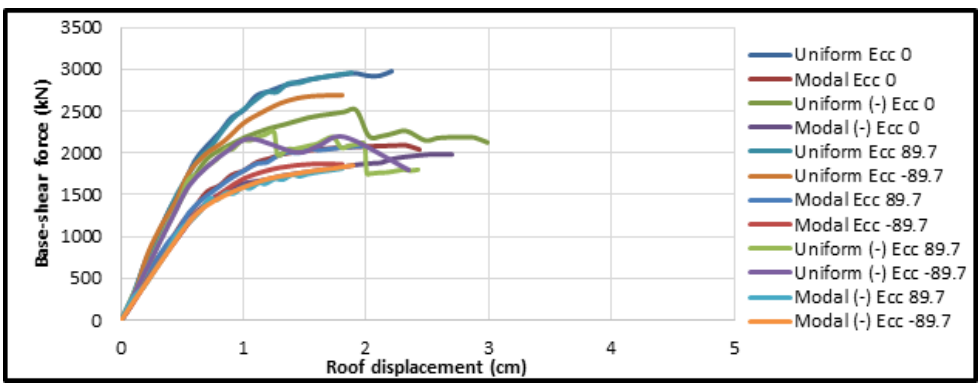

b) $y$-direction

Fig. 11 Capacity curves of the URM building with intervention 
The worst cases were taken as the representative pushover curves for both $\mathrm{x}$ - and $\mathrm{y}$ directions of the buildings. Normalized values of bilinear capacity curves are shown below (Fig. 12).

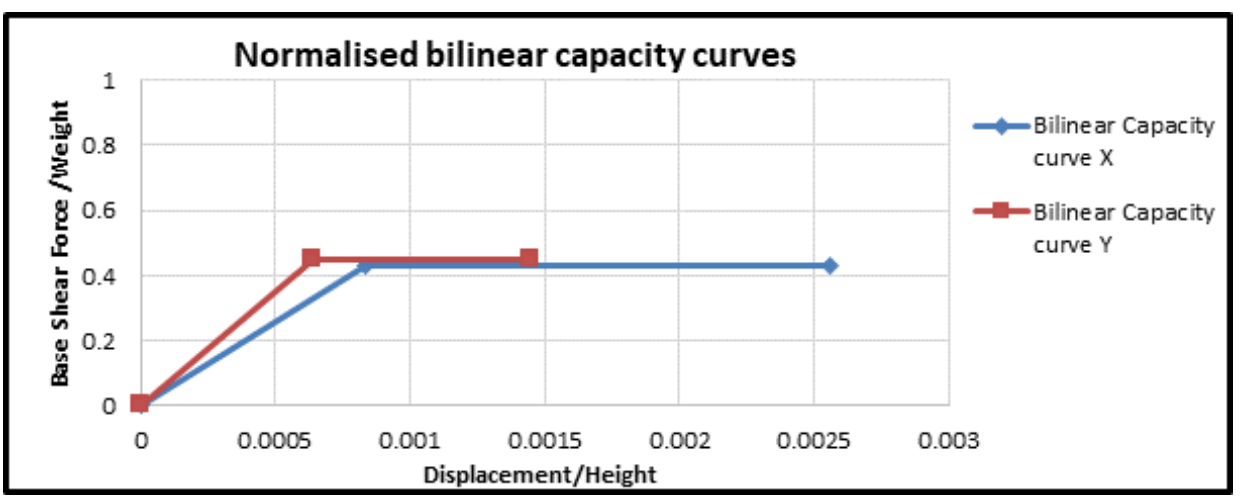

a)

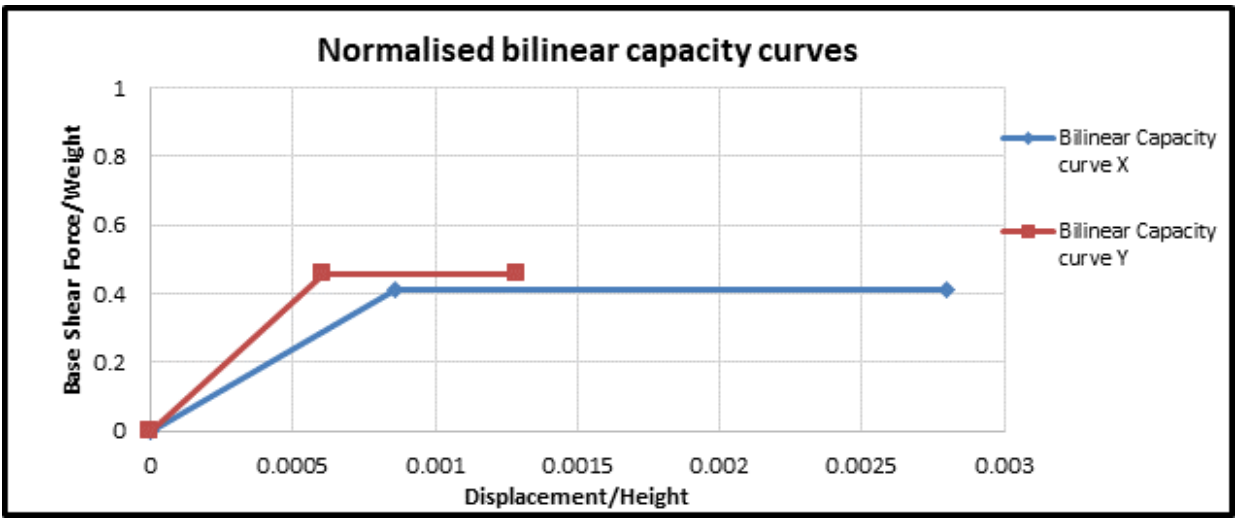

b)

Fig. 12 Normalized bilinear capacity curves; a) Original building, b) Building with intervention

Then, damage limit states of both buildings were evaluated using the criteria in Eurocode 8-3, and seismic capacities were estimated. The capacity assessment of the investigated buildings was performed using Eurocode 8, Part 3 [30]. Three limit states levels, i.e, "Damage Limitation (DL)", "Significant Damage (SD)" and "Near Collapse (NC)" are defined for performance evaluation.

In this study, performance evaluation of the buildings is done considering the soil Type- $\mathrm{C}$ with a moderate seismicity $(0.20 \mathrm{~g})$ according to Eurocode 8 [30] and its corresponding spectra considering Soil category II and medium seismicity in KTP-N2-89 [14]. For both buildings, these limit states were estimated, and maximum "ag" values were compared for each limit states. 
Table 2. Global drift capacities and seismic spectral acceleration capacities of studied buildings

\begin{tabular}{cccccccc}
\hline \multirow{2}{*}{ Building } & \multirow{2}{*}{ Direction } & \multicolumn{3}{c}{ Global Drift (mm) } & \multicolumn{3}{c}{ Spectral acceleration "ag" (m/s2) } \\
\cline { 2 - 8 } & & DL & SD & NC & DL & SD & NC \\
\hline \multirow{2}{*}{ Original Building } & $\mathrm{x}$ & 8.1 & 26.9 & 35.9 & 1.098 & 2.239 & 2.901 \\
Building with & $\mathrm{y}$ & 6.2 & 15.2 & 20.3 & 1.160 & 1.699 & 2.134 \\
intervention & $\mathrm{x}$ & 8.6 & 29.4 & 39.2 & 1.039 & 2.250 & 2.933 \\
\hline
\end{tabular}

The two structures in this study show different levels of seismic response. As can be seen from Table 2-3, the PGA $(\mathrm{ag})$ that can be sustained for the $N C$ state for the original building is near $0.22 \mathrm{~g}$ meanwhile for building with intervention is near $0.2 \mathrm{~g}$.

Table 3. Performance levels and their corresponding PGAs for the studied buildings

\begin{tabular}{ccccccc}
\hline Building & $0.12 \mathrm{~g}$ & $0.14 \mathrm{~g}$ & $0.16 \mathrm{~g}$ & $0.18 \mathrm{~g}$ & $0.2 \mathrm{~g}$ & $0.22 \mathrm{~g}$ \\
\hline \multirow{2}{*}{$\begin{array}{c}\text { Original Building } \\
\text { Building with intervention }\end{array}$} & $\mathrm{DL}$ & $\mathrm{DL}$ & $\mathrm{SD}$ & $\mathrm{NC}$ \\
\cline { 2 - 6 } & $\mathrm{C}$ & $\mathrm{SD}$ & $\mathrm{NC}$ \\
\hline
\end{tabular}

\subsection{Discussion of the Results}

From the comparison of the pushover curves of both buildings, in the $x$ - direction is viewed a decrease in stiffness and max base shear force, but a slight increase in displacement and ductility (Table 4). It must be said that this value is close, and the difference is at levels of 8.35\% for stiffness, $5.1 \%$ for max force, and $6 \%$ in ductility. Since the demolished walls were in this direction, the load bearing capacity has slightly decreased. Meanwhile, in ydirection happens the opposite. Since the walls in this direction are the same, but also columns had been added in first floor, the stiffness and maximum force, slightly increases, while ductility levels remain almost the same, with some little decrease. The values of initial stiffness change at a ratio of $6.6 \%$, the values of max force change at a ratio of $2.1 \%$ and the value of ductility at a ratio of $5.9 \%$.

Table 4. Comparison of the parameters before and after intervention of the selected URM building

\begin{tabular}{cccccc}
\hline & $\begin{array}{c}\text { Yield Force } \\
(\mathrm{kN})\end{array}$ & $\begin{array}{c}\text { Yield shear } \\
\text { Force/Weight }\end{array}$ & $\begin{array}{c}\text { Yield Disp. } \\
(\mathrm{cm})\end{array}$ & $\begin{array}{c}\text { Max Disp. } \\
(\mathrm{cm})\end{array}$ & Ductility \\
\hline URM-x & 1617 & 0.433 & 1.17 & 3.59 & 3.07 \\
$\begin{array}{c}\text { URM-x } \\
\text { +int }\end{array}$ & 1520 & 0.411 & 1.20 & 3.92 & 3.27 \\
$\begin{array}{c}\text { URM-y } \\
\text { URM-y } \\
\text { +int }\end{array}$ & 1670 & 0.447 & 0.90 & 2.03 & 2.26 \\
\hline
\end{tabular}

\section{Conclusion}

Recent earthquakes have revealed that URM structures built of masonry walls including openings have been shown to have poor seismic capacity. This paper presents the seismic capacity comparison of two typical mid-rise existing masonry buildings with and without interventions. In order to make a comparative assessment, two URM buildings having the same initial architectural and structural design were selected and modelled by using the TREMURI. The first building was constructed by using a template design and the second one was intervened by removing the first story walls and replaced them with RC frames in that direction. Member dimensions, material types and loading conditions of both 
buildings were determined from their architectural and structural designs projects and field investigations on considered buildings. Three dimensional structural models were simulated, and general properties of the members and material characteristics were determined based on experimental tests. The seismic capacities of the buildings were estimated by using a structural model which uses macro modelling approach for the load bearing masonry walls using TREMURI software package.

In this study, the influence of the removal of first floor load bearing walls on a typical URM building response has been investigated. The models are investigated using pushover analyses. The findings, expressed in terms of shear distributions and displacements, are compared with each other. The seismic demand has been defined by the response spectrum suggested by the EC 8 and the corresponding Albanian seismic codes. Based on the test results, the URM building was made of solid bricks with 7.3 MPa compressive strength and mortar with 2.4 MPa.

Damage levels were estimated according to Eurocode 8. The performance points were obtained and comparatively evaluated. The in-plane seismic capacity was found to be affected by the wall openings. Based on the analysis results, capacity curves obtained by pushover analyses reveal that URM building with intervention showed a slightly poor performance where the load bearing walls were removed and replaced by RC columns. On the other side, performance of the buildings was slightly increased due to the favorable effect of added columns on other direction. It does also show a higher shear capacity and lower ductile response.

Openings can decrease the stiffness of masonry walls and even alter the failure mechanisms of the masonry walls. Such irregular layout of openings may induce not only a non-uniform distribution of gravity loads between masonry panels but also may cause a concentration of seismic strength and drift demands in some parts of the wall. Accordingly, these interventions can lead to unfavorable damage concentrations increasing the seismic vulnerability of the entire wall, as shown by past earthquake inspections, i.e 2002 Molise, Italy earthquake [31].

This study shows that openings in load bearing walls can have a notable effect on the inplane seismic capacity of the URM structures. Based on the findings of this study, the authors suggest including geometrical irregularities within capacity models of URM walls with openings. Further research is needed to evaluate the influence of various number of openings on seismic capacity assessment of URM buildings. Moreover, one can investigate the effects of complex irregularity patterns on seismic capacity.

\section{References}

[1] Bilgin, H. and Hysenlliu, M. (2020). Comparison of near and far-fault ground motion effects on low and mid-rise masonry buildings, Journal of Building Engineering, Volume 30, 2020, 101248, ISSN 2352-7102. https://doi.org/10.1016/i.jobe.2020.101248

[2] Hysenlliu M, Bidaj A, Bilgin H. Influence of material properties on the seismic response of masonry buildings. Res. Eng. Struct. Mater., 2020; 6(4): 425-437. https://doi.org/10.17515/resm2020.177st0120

[3] Isik, E, Aydin MC, Buyuksarac A. (2020). 24 January 2020 Sivrice (Elazığ) earthquake damages and determination of earthquake parameters in the region. Earthquakes and Structures, 19 (2), 145-156. https://doi.org/10.1007/s10518-020-01018-4

[4] Ademović N, Hadzima-Nyarko M, Zagora N. Seismic vulnerability assessment of masonry buildings in Banja Luka and Sarajevo (Bosnia and Herzegovina) using the macroseismic model. Bull Earthquake Eng 18, 3897-3933 (2020). https://doi.org/10.1007/s10518-020-00846-8 
[5] Ozmen HB. A view on how to mitigate earthquake damages in Turkey from a civil engineering perspective. Res. Eng. Struct. Mater., 2021; 7(1): 1-11. http://dx.doi.org/10.17515/resm2020.231ea1113ed

[6] Milani G, Shehu R. Valente M. (2017). Seismic Vulnerability Mitigation of a Masonry Church by Means of CFRP Retrofitting. Procedia Engineering. Vol:195, 40-47. https://doi.org/10.1016/i.proeng.2017.04.521

[7] Hadzima-Nyarko M, Pavić G, Lešić M. Seismic vulnerability of old confined masonry buildings in Osijek, Croatia. Earthquakes and Structures. 2016,11(4):629-648. https://doi.org/10.12989/eas.2016.11.4.629

[8] Penna A, Morandi P, Rota M. et al. Performance of masonry buildings during the Emilia 2012 earthquake. Bull Earthquake Engineering. 2014(12):2255-2273. https://doi.org/10.1007/s10518-013-9496-6

[9] Yılmaz S, Tama YS, Bilgin H. Seismic performance evaluation of unreinforced masonry school buildings in Turkey. Journal of Vibration and Control. 2013,19(16):2421-2433. https://doi.org/10.1177/1077546312453190

[10] Pavić G, Hadzima-Nyarko M, Plaščak I, Pavić S. Seismic vulnerability assessment of historical unreinforced masonry buildings in Osijek using capacity spectrum method. Acta Physica Polonica. A, 135 (2019), 5; 1138-1141. https://doi.org/10.12693/APhysPolA.135.1138

[11] Kalman Šipoš T, Hadzima-Nyarko M. Seismic Risk of Croatian Cities Based on Building's Vulnerability. Tehnički vjesnik, 25 (2018), 4; 1088-1094. https://doi.org/10.17559/TV-20170708190145

[12] KTP-1963, Albanian masonry design code. (1963), (In Albanian).

[13] KTP-9-78, Albanian masonry design code. (1978), (In Albanian).

[14] KTP-N2-89, Albanian seismic design code. (1989), (In Albanian).

[15] EN 1996-1-1 (2005): Eurocode 6: Design of masonry structures - Part 1-1: General rules for reinforced and unreinforced masonry structures [Authority: The European Union Per Regulation 305/2011, Directive 98/34/EC, Directive 2004/18/EC].

[16] EN 1998-1 (2004), Eurocode 8: Design of Structures for Earthquake Resistance - Part 1: General Rules, Seismic Actions and Rules for Buildings, The European Union Per Regulation 305/2011, Directive 98/34/EC, Directive 2004/18/EC.

[17] Lagomarsino S, Penna A, Galasco A, Cattari S. TREMURI program: an equivalent frame model for the nonlinear seismic analysis of masonry buildings. Eng Struct. 2013(56):1787-99. https://doi.org/10.1016/i.engstruct.2013.08.002

[18] Ademović N, Kalman Šipoš T, Hadzima- Nyarko M. Rapid assessment of earthquake risk for Bosnia and Herzegovina. Bulletin of earthquake engineering, 18 (2020), 1835 1863. https://doi.org/10.1007/s10518-019-00775-1

[19] Kalman Šipoš T, Hadzima-Nyarko M. Rapid Seismic Risk Assessment. International Journal of Disaster Risk Reduction, 24 (2017), 348-360. https://doi.org/10.1016/j.ijdrr.2017.06.025

[20] Nato Sfp - 983054 (2007-2010). Harmonization of Seismic Hazard Maps for The Western Balkan Countries (Bshap).

[21] Aliaj S, Kociu S, Muco B, Sulstarova E. (2010). Seismicity, Seismo-tectonics and Seismic Hazard Assessment in Albania. The Academy of Sciences of Albania. ISBN: 978-9995610-26, Albania.

[22] Sulstarova E, Kociaj S, Aliaj Sh. (1980) "Seismic Regionalization of PSR of Albania." Publishing House of "8 Nentori" Tirana, 1980; 1-297.

[23] EN 772-1 (2000) European Standard: Methods of test for masonry units - Part 1: Determination of compressive strength, CEN, Brussels.

[24] EN 1015-11 (1999) European Standard: Methods of test for mortar for masonry - Part 11: Determination of flexural and compressive strength of hardened mortar, CEN, Brussels. 
[25] EN 1052-1, -3, -5 (1998) European Standard: Methods of test for masonry, CEN, Brussels.

[26] Lourenço PB. Computations on historic masonry structures. Progress in Structural Engineering and Materials. 2002,4(3):301-319. https://doi.org/10.1002/pse.120

[27] Gambarotta L, Lagomarsino S. On dynamic response of masonry panels. Proceedings of the national conference on 'Masonry mechanics between theory and practice', Messina, Italy, 1996.

[28] Pavić G, Hadzima-Nyarko M, Bulajić B. A Contribution to a UHS-Based Seismic Risk Assessment in Croatia-A Case Study for the City of Osijek. Sustainability, 12 (2020), 5; 1796, 24. https://doi.org/10.3390/su12051796

[29] Ademović N, Hadzima-Nyarko M, Zagora N. Seismic vulnerability assessment of masonry buildings in Banja Luka and Sarajevo (Bosnia and Herzegovina) using the macroseismic model. Bulletin of earthquake engineering, 18 (2020), 8; 3897-3933. https://doi.org/10.1007/s10518-020-00846-8

[30] EN 1998-1. European seismic design code. (2004). "Design of structures for earthquake resistance. Part 1: General rules, seismic actions and rules for buildings".

[31] Augenti N, Cosenza E, Dolce M, Manfredi G, Masi A, Samela L. Performance of school buildings during the 2002 Molise, Italy, earthquake. Earthquake Spectra 2004; 20(S1): S257-270. https://doi.org/10.1193/1.1769374 